\title{
Characteristic and Provenance of Sandstone Beds in Ngoro Oro Area, Patuk Sub district, Gunung Kidul Regency, Yogyakarta
}

\author{
$1^{\text {st }}$ Al Hussein Flowers Rizqi ${ }^{1}$ \\ alhussein@sttnas.ac.id ${ }^{1}$ \\ ${ }^{1}$ Departement of Geological Engineering, Institut Teknologi Nasional Yogyakarta
}

\begin{abstract}
Research area is located in physiography of northern part of Southern Mountain Zone, specific on Ngoro Oro road, Patuk subdistrict, Gunung Kidul Regency, Special Region of Yogyakarta, The aim of this research is characterization of sandstone in Semilir Formation. The method is about stratigraphical data using measuring section (MS) which done in the upper part of Semilir Formation. Based on petrographical analysis, the rocks from 3 samples were composed of dominated feldspar (21-40\%), lithic (28-51\%) and also amount of quartz (1-6\%) with matrix about $22-27 \%$ also carbonate cement so the name of rocks are Calcareous Felspathic Wacke and Calcareous Lithic Wacke. The result of plotting diagram based on composition of quartz, feldspar and lithic on QPL paleoclimate diagram showed that the sandstone come out from plutonic provenance on semiarid climated, the QPL diagram also showed that the source of Sandstone origin come from magmatic arc, sub zone of Dissected Arc which indicated that the source from igneous rock. The origin of igneous rock could be interpreted as Kebobutak Formation.
\end{abstract}

Keywords: sandstone, provenance, Semilir, Ngoro Oro, petrography

\section{Introduction}

The new road which has been constructed in Ngoro Oro area, exposed the new outcrop of sedimentary - vulcaniclastic layer since last year. Only a few of stratigraphy researchs in this area has been made, but there is no author who did the specific research about the provenance of sandstone in Ngoro Oro. The Research area is located in physiography of northern part of Southern Mountain Zone, specific on Ngoro Oro road, Patuk subdistrict, Gunung Kidul Regency, Special Region of Yogyakarta (Figure 1). Based on the map of Yogyakarta Regional Geology (Rahardjo et al, 1977) and Surakarta - Giritontro (Surono et al, 1992) (Figure 2), the research area is located in Semilir Formation. The aim of this research is about characteristic and provenance of sandstone bed.

Based on the Efendi et all (2013), the Semilir Formation developed gradually into Buyutan Member in early Miocene. On the lower part, the Semilir Formation composed of interbedded of tuffaceous sandstone and siltstone also volcanic breccias in other part. On the upper part, this Buyutan Member has a lithology consisting of tuffaceous sandstone and conglomerates and siltstone that rich in Carbon.

Based on the regional stratigraphy, the age of Semilir Formation in some research showed the different ages. The result of small foraminiferal analysis showed that the Semilir Formation at Early Miocene to Middle Miocene (Sumarso and Ismoyowati, 1975) and Late Oligocene to Early Miocene (Rahardjo et al, 1995). The result of absolute age was taken by U$\mathrm{Pb}$ method showed that 20 million years ago (Early Miocene) (Smyth, 2005). Semilir Formation was deposited on land to marine. Amount of tuffaceous composition and pumice in a large 
amount could be interpreted that Semilir Formation was produced form a big explosion and damaged, associated with a caldera formed.

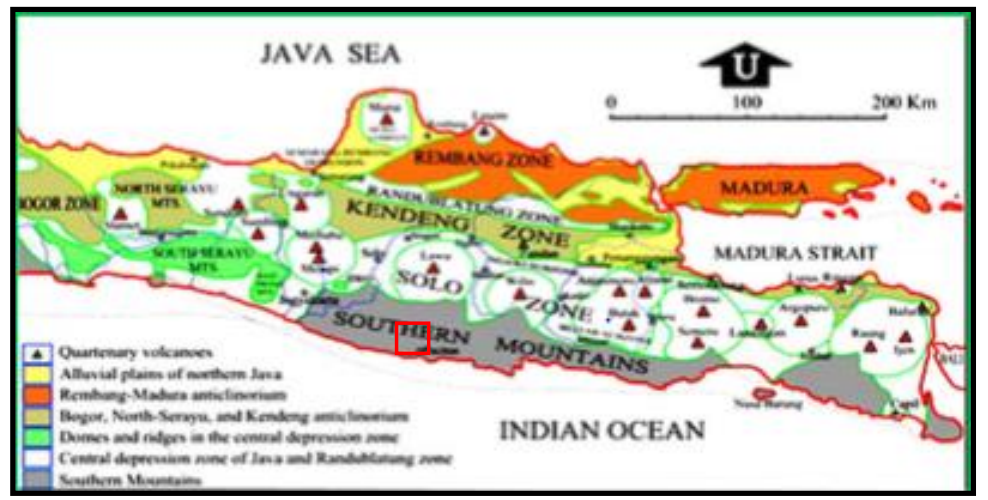

Fig. 1. The physiography of research area included in Southern Mountain (Van Bemmelen, 1949). The research area showed in red box

Based on volcanology research, Hartono (2000) and Bronto (2009), assumed that the origin and source of rocks in Bayat area colud be related to volcanism activities. The volcanism activity related to the presence of lava, andesitic lava, dyke, and sill in Bayat area. The presence of sandstone in the research area revealed that the volcanism activity in Semilir Formation has a different characteristic from the research which published such as Bronto (2009), interpreted the volcanic eruption produced the ignimbrite breccias has Katmai type in the surround of Song Putri and Parang Joho dam in Wonogiri. In research area, there were the sandstone bed which has different characteristic and interested to further study.

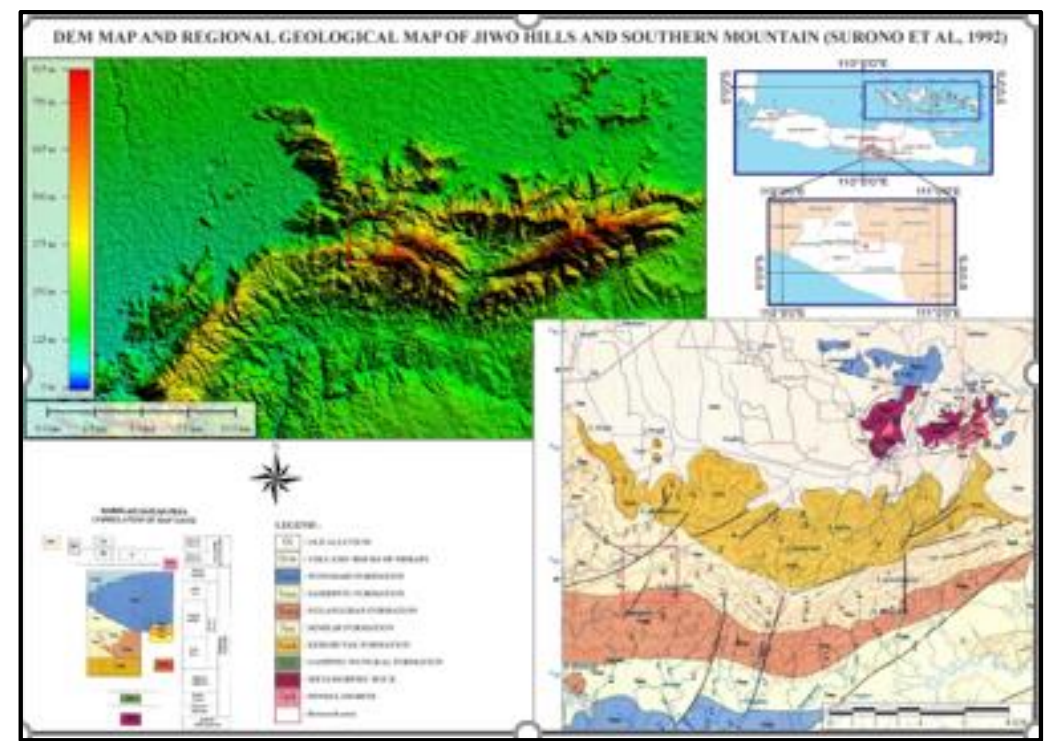

Fig. 2. The regional geological map scale of 1:100.000 for research area (Surono et al 1992 and Rahardjo et al 1996). The research area is in the red box 
The research area administratively is located in Ngoro Oro area, Patuk sub district, Gunung Kidul Regency, Specific Region of Yogyakarta. Geographically, the research area is located in coordinate of UTM Zone 49S $9134000 \mathrm{mN}-9135500 \mathrm{mN}$ and $448000 \mathrm{mE}-449500$ $\mathrm{mE}$. The data was taken on the side of road in Ngoro Oro and the northside of Petir river (north of bridge) (Figure 3).

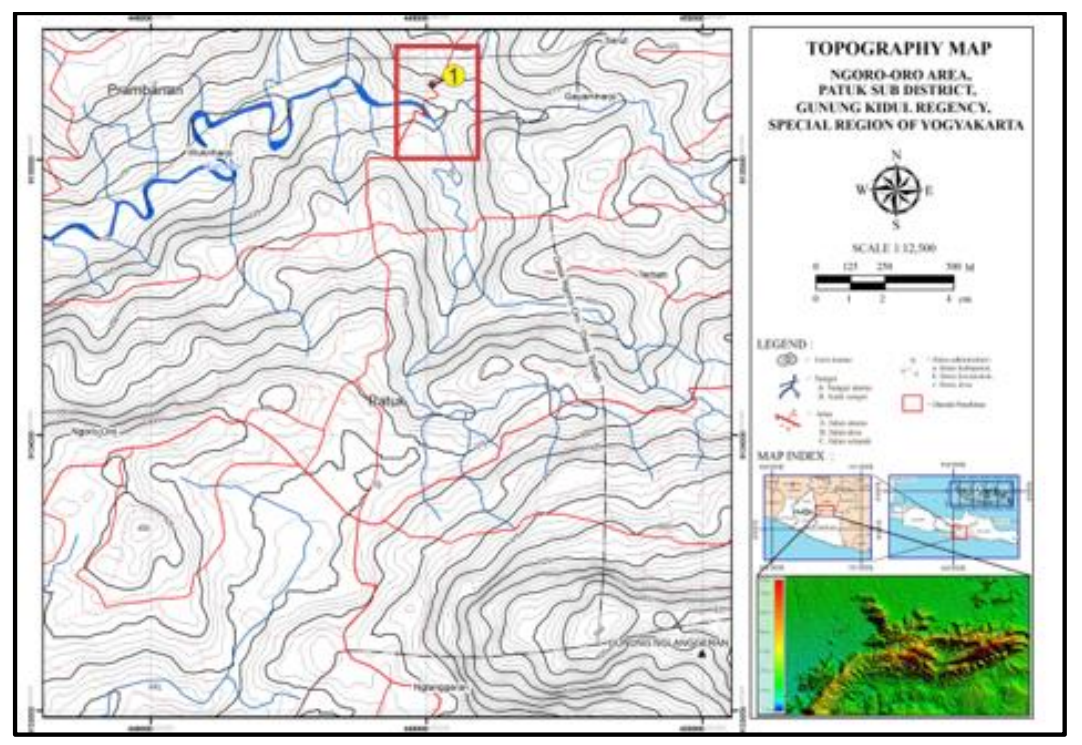

Fig. 3. The map of observation point, the research area in point of observation 1 in Ngoro Oro (research area is in red box)

\section{Research Methods}

In this research, there were some steps (Figure 4).

\subsection{Study of Literature}

The result of literature review is used for supported data (secondary data). The collecting data of geological reports from researcher in many literatures about overview of regional geology in Southern Mountain, specially in research area.

\subsection{Data Observation and Rock Sampling on field}

The data observation done by this following steps :

\subsubsection{Measuring section of stratigraphy section}

The observation data done by measuring section of stratigraphy in the side of road. Megascopic observation of rock sample done by detailed description in sedimentary structure, trace fossil, paleocurrent analysis on the field. 


\subsubsection{Sampling of lithology (rock sample)}

Sampling of lithology done in layers of sedimentary rock specificly in sandstone bed. The rock sampling is used for petrographical analysis.

\subsection{Studio analysis and laboratory analysis}

Studio analysis done by reconstruction of stratigraphy measuring section and determine the margin of sandstone bed. Laboratory analysis was done by analysis of petrography thin section in three samples. The age and depositional environment determination done in some samples such as shale by observation in planktonic and benthonic foraminifera. The plotting data in QFL diagram showed the provenance of sandstone rock sample.

\subsection{Data Evaluation}

In this step, the interpretation and integration data done comprehensively to stratigraphy data and result of petrography analysis. The provenance of sandstone beds would be compared to the result of last research.

\subsection{Reporting}

The finishing step is make a conclusion and reporting. The report such as a paper would be published in any accreditation journal or paper.

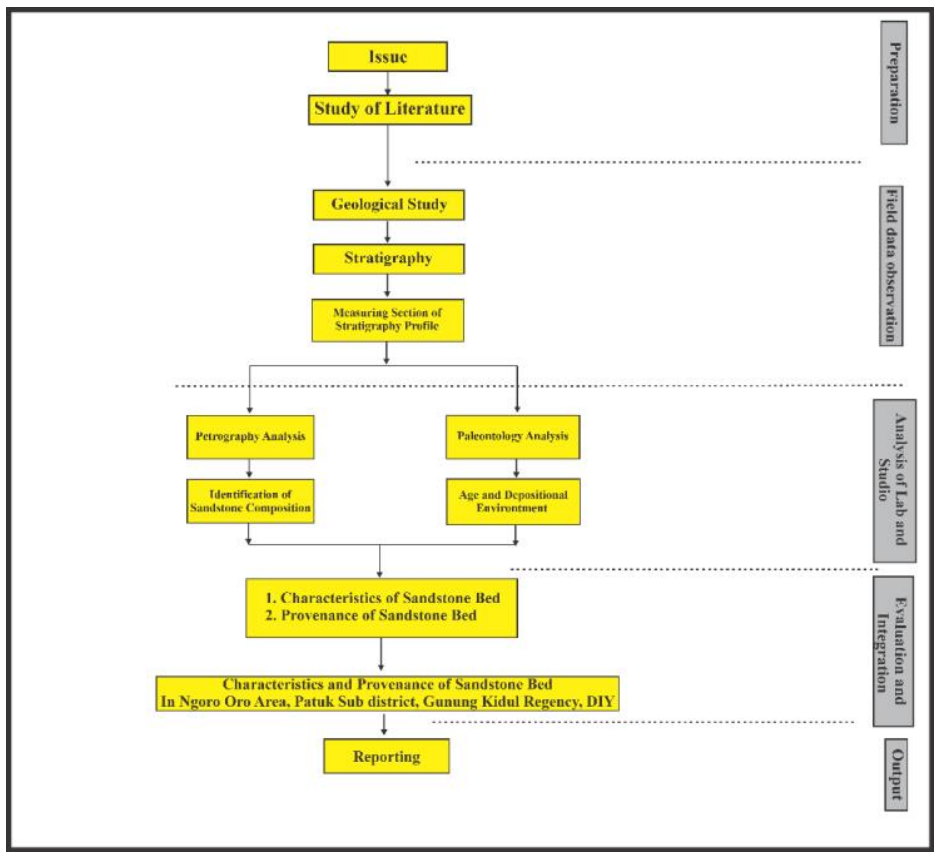

Fig. 4. The scheme of research 


\section{The Results and The Discussions}

\subsection{Stratigraphy}

Observing to the lithology data done by measuring section with jacob's method. The track of measuring section started on the siliciclastic and volcaniclastic rocks at northern part of bridge. On this observation point, the measuring section done with thickness of 7,8 metres. The lithology in this section is consisting of shale inserted by carbon lens, polymics breccias with interbedded of sandstone bed, tuffaceous siltstone, and massive sandstone (Figure 5). The analysis of age of sedimentary rocks in this section done in foraminiferal analysis either planktonic or benthonic. The result of analysis is there is no fossil inside the rock samples. It showed that to determined the age of rocks, the correlation was done related to regional stratigraphy (age at N5 - N9, Sumarso et al, 1975) must be done.

\subsection{Characteristics of Sandstone}

The detail description of outcrop started at observed in rock colour, sedimentary structures, texture, composition, and name of rock. The three layer of sandstone beds at observation location showed the tightness of rock is very tight. A number of sample (three samples) were taken to described in handspeciment or in petrography analysis (Figure 6). The code of rock samples was named by PTR 1.2 (lower bed), PTR 1.3 (middle bed) and PTR 1.4 (upper bed).



Fig. 5. The reconstruction of measuring stratigraphy and rock description in observation point

The characteristic of rock sample at PTR 1.2 was identified by handspecimet description. Its dark grey coloured, the layer of sedimentary rocks is parallel with the general layer and formed as lenses shape), the grain size is coarsed to very coarsed, well to poor sorted, the composition of rock consisted of feldspar, pyroxene, biotite, quartz and carbonate. The tightness is very hard. 




Fig. 6. The sandstone outcrop in research area has three layers.

The characteristic of rock sample at PTR 1.3 is not different with PTR 1.2, it's identified by handspecimet description. The dimension of rock is longer than PTR 1.2. Its brown to grey coloured, the layer of sedimentary rocks is parallel with the general layer and formed as lenses shape), the grain size is coarsed to very coarsed, well to poor sorted, the composition of rock consisted of feldspar, pyroxene, biotite, quartz and carbonate. The tightness is very hard.

The characteristic of rock sample at PTR 1.4 was identified by handspecimet description. The dimension of rock in length has a shortest size. Its dark brown to grey coloured, the layer of sedimentary rocks is parallel with the general layer and formed as lenses shape), the grain size is coarsed to very coarsed, well to poor sorted, the composition of rock consisted of feldspar, pyroxene, biotite, quartz and carbonate. The tightness is very hard.

\subsection{Analysis of Microscopic thin section}

Analysis of microscopic was done in three samples (PTR 1.2, PTR 1.3, PTR 1.4.) of sandstone. The result of analysis showed that rock included in sedimentary rock, massive structure, grain size is $<2 \mathrm{~mm}$, the grain shape is subrounded to subangular, closed fabric, moderated sorted, the composition is consisting of feldspar abunandce of $40 \%$, matrix such as micrite abunandce of $26 \%$, a few of lithic abunandce of $9 \%$ and quartz abunandce of $6 \%$ (Figure 7). Based on rock description in microscopic analysis, the name of rock on PTR 1.2 is Calcaroeus Felspathic Wacke (Pettijohn, 1975).
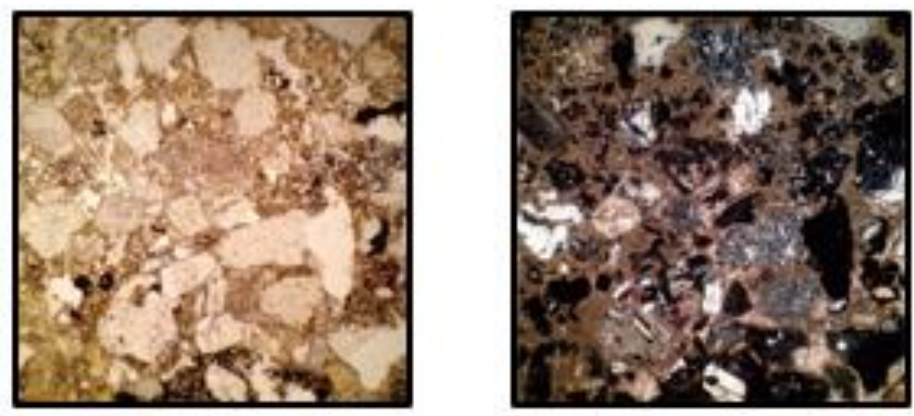

Fig. 7. The microscopic thin section at sample PTR 1.2 with Parallel Polarized Light (PPL) on the left and Cross Polarized Light (XPL) on the right. 
The description is not so different from another sample such as PTR 1.3. Based on physical properties of rock on microscopic analysis is that rock included in sedimentary rock, massive structure, grain size is $<2 \mathrm{~mm}$, the grain shape is subrounded to subangular, closed fabric, moderate sorted, the composition is consisting of feldspar abunandce of $36 \%$, matrix such as micrite abunandce of $22 \%$, a few of lithic abunandce of $38 \%$ and quartz abunandce of $4 \%$ (Figure 8). Based on these description of microscopic analysis, the name of rock on PTR 1.3 is Calcaroeus Lithic Wacke (Pettijohn, 1975).
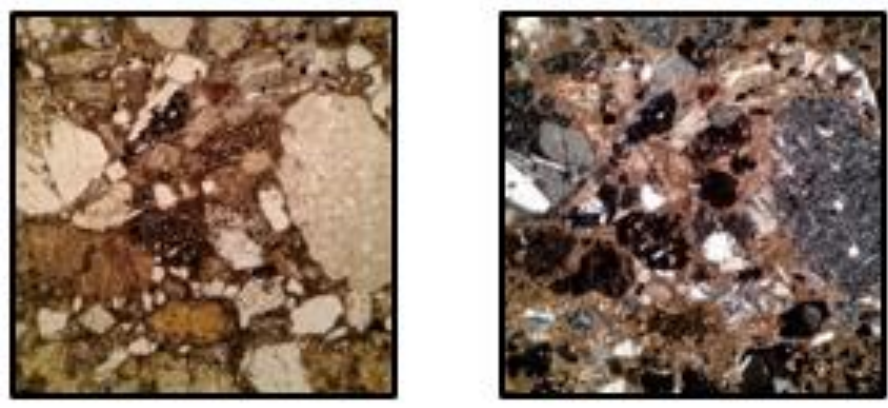

Fig. 7. The microscopic thin section at sample PTR 1.3 with Parallel Polarized Light (PPL) on the left and Cross Polarized Light (XPL) on the right.

The description of microscopic analysis in PTR 1.4. Based on physical properties of rock on microscopic analysis is that rock included in sedimentary rock, massive structure, grain size is $<2 \mathrm{~mm}$, the grain shape is subrounded to subangular, closed fabric, moderate sorted, the composition is consisting of feldspar abunandce of $21 \%$, matrix such as micrite abunandce of $27 \%$, a few of lithic abunandce of $49 \%$ and quartz abunandce of $1 \%$ (Figure 9 ). Based on these description of microscopic analysis, the name of rock on sample code of PTR 1.4 is Calcaroeus Lithic Wacke (Pettijohn, 1975).

The presence of Calcareous Felspathic Wacke and Calcareous Lithic Wacke, showed that the composition of the rock effected by interact of some aspects such as early composition of source of the rock, climate, tectonic setting, and depositional process. Interaction of these aspects modified the sedimentary rock composition during the depositional process from the source area to the depositional environtment. (Table 1). The existence of three layer of sandstone could be interpreted as a part of Semilir Formation stratigraphy unit which is rich in lithic and feldspar. This sandstone is different from the sandstones were founded and identified by Rizkianto (2015) which has a number of quartz in larger composition.
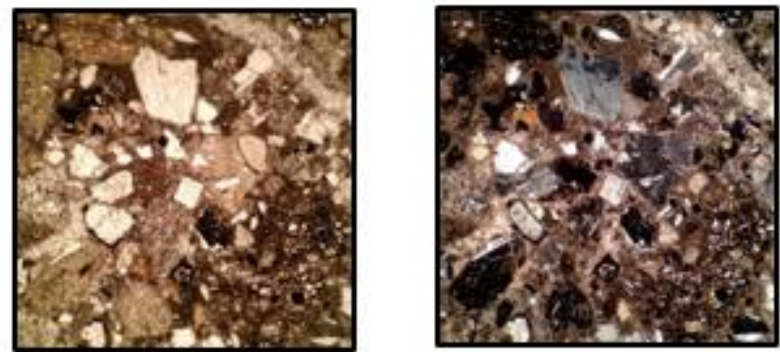

Fig. 9. The microscopic thin section at sample PTR 1.4 with Parallel Polarized Light (PPL) on the left and Cross Polarized Light (XPL) on the right. 
Table 1. The composition of minerals in sandstone rock samples (in procentages)

\begin{tabular}{ccccccc}
\hline No & Rock Sample & Quartz & Feldspar & Lithic & Matrix & Name of rock \\
\hline $\mathbf{1}$ & PTR 1.2 & 6 & 40 & 28 & 26 & $\begin{array}{c}\text { Calcareous } \\
\text { Felspathic Wacke }\end{array}$ \\
$\mathbf{2}$ & PTR 1.3 & 4 & 36 & 38 & 22 & $\begin{array}{c}\text { Calcareous Lithic } \\
\text { Wacke } \\
\text { Calcareous Lithic } \\
\text { Wacke }\end{array}$ \\
\hline
\end{tabular}

\section{Provenance of sandstone}

Among the controlling aspects, the tectonic setting is a main aspect for the variation of the rock composition (Dickinson, 1985). Tectonic process effected the lithology properties and geochemical of sedimentary rocks in two ways. (1) The tectonic setting has their own provenance characteristics. and (2) The tectonic setting is characterized by the sedimentation process. Due to those reasons, to know the provenance of the sedimentary rocks could be identified by past tectonic setting (Dickinson et al 1983).

The term of provenance is used by petrography analysis expert, to all the things related to process which produced of sediments or sedimentary rocks. The main aspects in study of provenance is a source rock identification, climate, tectonic setting of source area (Schieber, 1989). Climate in a source area could be interpreted from the roundness of grain size and index of feldspar alteration (Folk, 1980). Kinds of source rock could be interpreted from comparation of monocrystalline and polycrystalline quartz grain (Basu, 1975), on other side the tectonic setting of source area could be determined by proportion of some components such as quartz, ( $\mathrm{Q}=$ Quartz), feldspar $(\mathrm{F}=$ Feldspar), and lithic fragments $(\mathrm{L}=$ Lithic fragment) (Dickinson and Suczek, 1979).

\subsection{Interpretation of Climate in Source Area}

Climate is very controlled by position of latitude and the distance of the ocean. The humid Tropical climate generally there in the closer area to equator area. The arid climate to semi-arid generally is far from the ocean and located in sub tropic latitude. During climate controlling the weathering process, the weathering will be occurred more effectively and intensively in humid climate than arid to semi-arid climate. These proved on the condition of sediments which would be produced.

The recent research on sand deposits were produced by plutonic igneous rocks, could be founded that on semi-arid climate produced the sand with the quartz proportion less than the other composition and the lithic is in bigger proportion. By plotting on QFL diagram, the sand deposits were produced by metamorphic source area on semi-arid climate which produced the quartz in a small proportion. The result of sample plotting on QFL diagram (Nelson, 2007) showed that the source area of major is in semi-arid climate or semi-dry such as generally on tropical climate (Figure 10). 


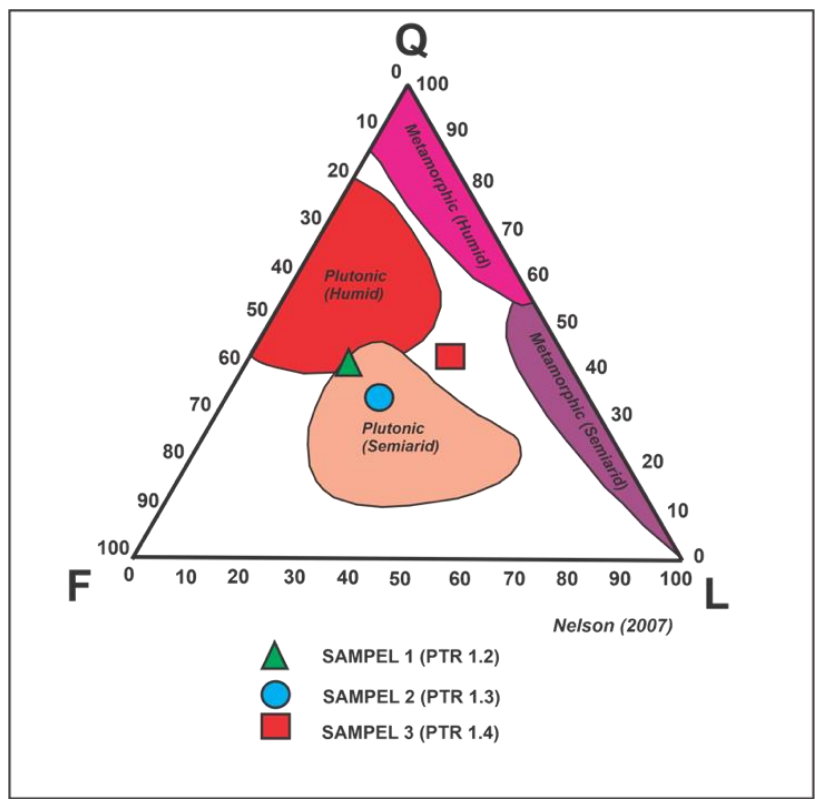

Fig. 10. The result of paleoclimate plotting on QFL diagram (Nelson, 2007) showed that a major sample come from semiarid climate

\subsection{Interpretation of Tectonic Setting}

Dickinson (1985) assumed that the sandstone composition reflected to not only the source area but also the tectonic setting in source area. The main assumption on basic study of provenance is the difference of tectonic setting comprising of kind of rock which has characteristic if the rock eroded would produced the sandstone in a specific composition range.

Analysis of sandstone which the provenance has been interpreted by identify the range of composition as reference to determinate the provenance of other sandstone samples. Dickinson and Suczek (1979) assumed that QFL diagram (Figure 11) related to sandstone detritus sample with a kind of main provenance consisted of continental block provenance (such as subprovenance craton interior, transitional, and uplifted basement), magmatic arc provenance (such as sub-provenance undissected arc, transitional arc, and dissected arc), and recycled orogen provenance (such as sub-provenance subduction complex, collision orogen, and foreland uplift).

The sandstone in the research area on sample of PTR 1.2 and PTR 1.3 are included in Magmatic Arc Provenance area comprised of sub zona Dissected Arc. This is showed that a big part of source area come from igneous rock. Those igneous rock could be interpreted from the rock formation before the Semilir Formation was deposited, it's Kebobutak Formation which was deposited in turbidite environtment (Sumarso and Ismoyowati, 1975). On other side, the sample of PTR 1.4 is included in Recycled Orogenic area could interpreted as a resedimentation of the metamorphic rocks from basement rock in the northern area (Bayat, Klaten, Central Java) (Figure 11). 


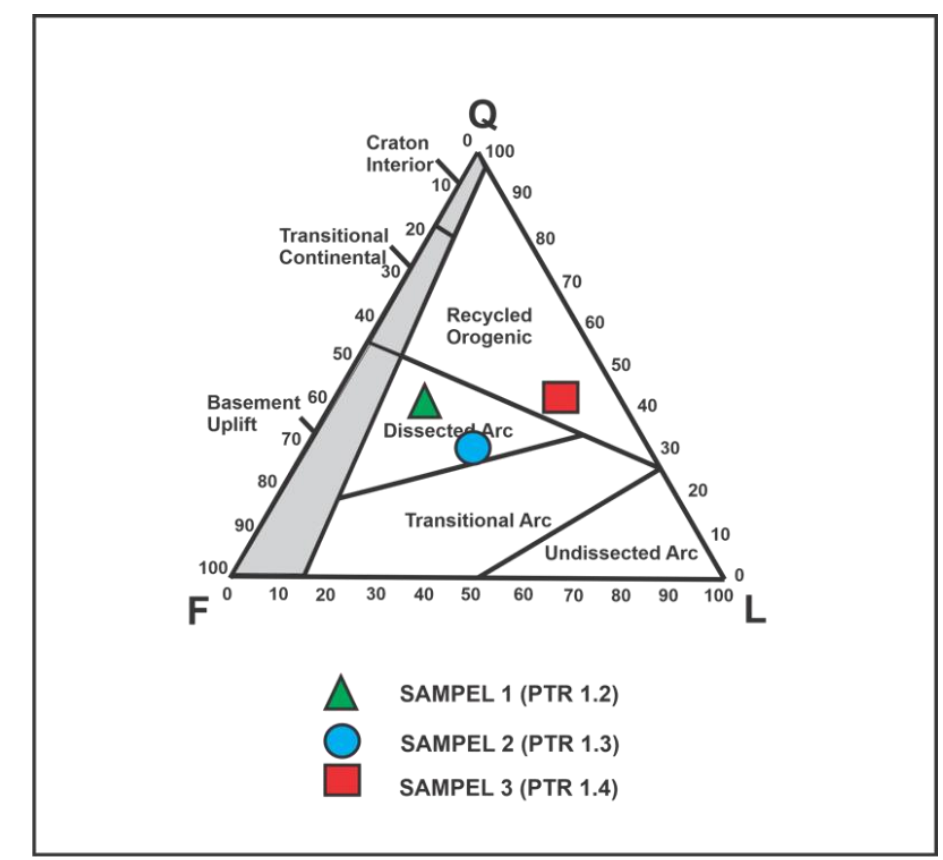

Fig. 11. The result of plotting on QFL diagram (Dickinson and Suczek, 1979). A big part of sample is included in Magmatic Arc Provenance area comprised of Dissected Arc. A little part of sample is included in Recycled Orogenic that interpreted from Bayat.

\section{Conclusion}

Based on field observation, analysis of studio, and interpretation of data, the research area on the stratigraphy section consisted of shale with carbon lenses, polymics breccias, calcareous felspathic wacke, calcareous lithic wacke, tuffaceous siltstone and massive sandstone. The thickness of stratigraphy measuring section is 7,8 metres. According to petrographic analysis, the rock composition in three sample dominated by feldspar (21-40\%), lithic (28-51\%) and amount of quartz (1-6\%) with matrix in procentage of 22-27\% also carbonate cement so that the name of rocks are Calcareous Felspathic Wacke and Calcareous Lithic Wacke. The result of plotting on QFL diagram showed that the sandstone from plutonic rocks in semiarid climate. The plotting on QPL diagram also showed that the source of rock come from magmatic arc provenance, sub zone of Dissected Arc which is indicated that the source rock could be interpreted from the rock formation before the Semilir Formation deposited, it's Kebobutak Formation which was deposited in turbidite environtment.

\section{Acknowledgments}

Authors wishing to acknowledge for Institut Teknologi Nasional Yogyakarta who has funding this research. Thank to field assistant Irghy Reynaldi Adam and Purwita Rosa Nugraheni for guiding on the field. 


\section{Reference}

[1] Surono, T., B., and Sudarno, I., 1992. Geological Map of Surakarta-Giritontro Sheet, Java, scale, 1 (100.000).

[2] Rahardjo, W., Sukandarrumidi, and H.M.D. Rosidi (1977) . Geological Map of Yogyakarta Sheet, Java, Geological Research and Development Center, Bandung.

[3] Efendi, W.V., Novian, M.I. and Utama, R.W., 2014. Stratigraphy of Semilir Formation in Krakitan village, Candirejo, Semin sub district, Gunung Kidul Regency, Special Regon of Yogyakarta. In Prosiding of $7^{\text {th }}$ National Earth Seminar and National Symposium of Geological Science

[4] Sumarso, T.I., 1975. Contribution to the Stratigraphy of the Jiwo Hills and Their Southern Surroundings (Central Java).

[5] Rahardjo, W., Sukandarrumidi, and H.M.D. Rosidi (1995) Geological Map of Yogyakarta Sheet Java, second edition, Geological Research and Development Center, Bandung.

[6] Smyth et al, 2005, East Java: Cenozoic Basins Volcanoes and Ancient Basement, Proceedings IPA, 30th Annual Convention \& Exhibition, IPA05-G-045.

[7] Van Bemmelen, R.W., 1949, The Geology of Indonesia Vol. IA, General Geology of Indonesia and Adjacent Archipelago, Government Printing Office, The Hague.

[8] Hartono, G., 2000. Study of Tertiary volcanoes: the distribution of eruption center and petrology in Southern Mountain, Yogyakarta. Tesis of magister, study Program of Geological Engineering Departement, Magister Program, ITB, Bandung, 168 h, (not published).

[9] Bronto, S., Mulyaningsih, S., Hartono, G. and Astuti, B., 2009. Parangjoho and Songputri dam: An Alternative of eruption source of Semilir Formation in Eromoko area, Wonogiri Regency, Central Java. Indonesian Journal on Geoscience, 4(2), pp.77-92.

[10] Dickinson, W.R and Seely, D.R (1979): Structure and Stratigraphy of forearc region, AAPG Bulletin, V.63, No.1, 2-31

[11] Dickinson, W.R., Beard, L.S., Brakenbridge, G.R., Erjavec, J.L., Ferguson, R.C., Inman, K.F., Knepp, R.A., Lindberg, F.A., dan Ryberg, P.T. (1983): Provenance of North American Phanerozoic sandstone in relation to tectonic setting, Geol. Soc. Am. Bull., 94, 222-235

[12] Schieber, J. (1989): A combined petrographical-geochemical provenance study of the Newland Formation, Mid-Proterozoic of Montana, Sedimentology, 36, p.203-21

[13] Folk, R.L. (1980) : Petrology of sedimentary rocks, Austin, Texas, Hemphill Publication Company, $182 \mathrm{p}$

[14] Rizkianto, Y. (2015). Geology and Study of provenance of Semilir Volcanic Sandstone in Sambirejo Area, Ngawen Sub district, Gunung Kidul Regency, Special Region of Yogyakarta (Doctoral dissertation, UPN" Veteran" Yogyakarta).

[15] Pettijohn, F.J., 1975, Sedimentary Rocks: Thrid Edition, Happer \& Row Publisher, New York.

[16] Nelson, S.A. (2007): Petrology: Sandstone and conglomerate, http://www.tulane.edu/ sanelson/geol 212, down load pada 25 April 2007. 